AGRICULTURE AND BIOLOGY JOURNAL OF NORTH AMERICA

ISSN Print: 2151-7517, ISSN Online: 2151-7525, doi:10.5251/abjna.2012.3.3.82.92

(C) 2012, ScienceHu $\beta$, http://www.scihub.org/ABJNA

\title{
The effects of green manure and NPK fertilizer on the growth and yield of maize (Zea mays $L$ ) in the mount Cameroon region
}

\author{
Egbe E. $A^{* 1}$ Fonge, B.A ${ }^{1}$, Mokake. S. $E^{1}$, Besong. $M^{2}$ and Fongod $A N^{1}$ \\ ${ }^{1}$ Department of Plant and Animal Sciences, University of Buea, P.O.BOX 63 Buea, \\ Cameroon \\ ${ }^{2}$ Institute of Agronomic Research for Development (IRAD) Ekona
}

\begin{abstract}
This study was carried out in the Mount Cameroon region to evaluate the effects of green manure and fertilizer on the growth and yield of maize. There were eight treatments: Calliandra prunings, Calliandra prunings + fertilizer $(60 \mathrm{~kg} / \mathrm{ha}$ NPK), Gliricidia prunings, Gliricidia prunings + fertilizer, Senna prunings, Senna prunings + fertilizer, fertilizer only $(120 \mathrm{~kg} / \mathrm{ha}$ NPK) and control. Results showed that biomass of prunings in the first pruning was highest in Calliandra $(5314 \mathrm{~kg} / \mathrm{ha})$ and this was significantly different from those of Senna $(2909 \mathrm{~kg} / \mathrm{ha})$ and Gliricidia $(2112 \mathrm{~kg} / \mathrm{ha})$. Nitrogen input from the prunings was highly significant $(P<0.05)$ in Calliandra prunings $(217$ $\mathrm{kgN} / \mathrm{ha}$ ) and least in Gliricidia species $(69.0 \mathrm{kgN} / \mathrm{ha})$. Maize grain yield in the different treatments was not significantly different in the first and second planting seasons. The highest grain yield during the third cropping season was observed in Calliandra + fertilizer $(4696 \mathrm{~kg} / \mathrm{ha})$ and least in control $(3332 \mathrm{~kg} / \mathrm{ha})$. It was also noted that nitrogen uptake was highest in plots supplied with fertilizer only and lowest in control. Weed biomass was highest in control and in plots supplied with fertilizer only. Soil chemical changes after three cropping periods showed variable changes in treatments. There was decrease in bulk density in plots supplied with Calliandra prunings.
\end{abstract}

Key words: Leguminous, prunings, grain yield, Soil nutrient changes and nitrogen uptake

\section{INTRODUCTION}

An increase in world population is causing pressure on land leading to the replacement of traditional shifting cultivation. Adoption of inappropriate farming methods has resulted in land degradation and clearance of new forest land for agriculture. Application of plant residues is a well known agricultural practice for maintaining soil nutrients levels and ameliorating soil physical properties to sustain crop production (Fu et al 1987). Egbe et al (1998) indicated that plant residues from planted fallows or prunings from hedgerows in alley cropping systems can contribute significant quantities of nutrients to the associated crops. McDonald et al (2004) indicated that crop plants growing in the agroforestry plots had significantly higher growth and yield than those in purely arable crop plots.

Farmers in the mid-altitudes of mount Cameroon region carry out farming on originally rich volcanic soils that are now degrading because of high land pressure, erosion and lack of good soil management practices to maintain its fertility. Maize is a primary staple grain for many Cameroonians and consumption has steadily increased during the last
20 years. It is also used in industries especially the beer and pharmaceutical industries. Farmers throughout the nation's ten regions work hard to grow enough maize to meet the demand of the population (NCRE 1991). Ecosystem biogeochemistry may be strongly influenced by plant species acting in concert with abiotic factors (Hobbie 1992). As a result, changes in vegetation composition can produce substantial changes in carbon and nitrogen dynamics (Vitousek 1997, Tilman et al. 1997). The nutrient content of organic fertilizers vary widely depending on the source and moisture content and there is also the problem of slow and variable release rates of nutrients during decomposition of organic materials (Hseih and Hseih 1990). Though organic fertilizers supply large quantities of nitrogen required by crops to obtain maximum yield but for a more sustainable productive system, there is the need to supplement organic fertilizers with inorganic fertilizers (Jama et al, 2000 and Vanlauwe et al, 2001)

Soil properties in these fertile soils may be affected by species composition. Leguminous trees may enhance soil $\mathrm{C}$ and $\mathrm{N}$ in some cases but not in others (Abrams et al. 1990). In some instances, soil $\mathrm{N}$ pools 
in patches dominated by woody leguminous species may be greater than that of patches dominated by nonleguminous woody plants (Vitousek and Walker 1989). In other cases, $\mathrm{N}$ pools or mineralization rates may be comparable between legume and nonwoody legume patches (Belsky et al. 1993) and between deciduous tree legume and evergreen shrub patches (Mazzarino et al. 1991). This is true because not all leguminous plants carry out biological nitrogen fixation.

The performance of some nonlegumes having higher nutrient inputs to the soil than some legumes was also reported by Barrios and Cobo (2004) for Tithonia diversifola (nonlegume) and Calliandra calothyrsus (legume). Jaiyebo and Moore (1964) had reported that trees and shrubs which are deeply rooted are more efficient in nutrient recycling than grasses and herbs. The study would therefore evaluate the effects of green manure and fertilizer as nutrient inputs to the soil for sustainable production of maize within the mount Cameroon region. Research in this area would improve on effective land use management and also sustainable crop production on long-term basis.

\section{MATERIALS AND METHODS}

Study site: This study was carried out at the Institute of Agricultural Research for Development (IRAD) Ekona which lies within latitude $12^{\circ} 9.09^{1} \mathrm{~N}$ and longitude $9^{\circ} 20.57^{1} \mathrm{E}$. It is located in Fako division of the Southwest region of Cameroon and in the Coastal belt of the Gulf of Guinea (Ndam 1998). It has a mean annual rainfall of $2085 \mathrm{~mm}$, mean monthly temperature range of $19-30^{\circ} \mathrm{C}$ and mean annual relative humidity of $86 \%$. Ekona has an elevation of $450 \mathrm{~m}$ above sea level and it is in the lower slopes of mount Cameroon and has old and young volcanic soils. The old volcanic soils are highly weathered, deeper, brown to reddish brown and are poor in plant nutrients. The young volcanic soils are in the upper slopes of the mountain and are shallow and rich in plant nutrients (andosols). They are intensively cultivated and thereby leading to a decline in soil fertility (FAO 1977, Awah E.T personal communication). The cropping was carried out on old volcanic soil. The farming system in this region is mostly slash and burn agriculture.

Field layout: The research site had been left to fallow for three years with already established Senna siamea, Gliricidia sepium and Callandria calothyrsus hedgerows. The length of the hedgerows was $7.5 \mathrm{~m}$ and the width of the alleys was $4 \mathrm{~m}$. The inrtrarow spacing of the hedge plants were $0.25 \mathrm{~m}$ and maize was used as test crop. The design was a randomised complete block design with three replicates. There were seven treatments: Callandria prunings, Callandria prunings plus fertilizer, Gliricidia prunings, Gliricidia prunings plus fertilizer, Senna prunings, Senna prunings plus fertilizer, fertilizer only and control (no prunings/hedgerow or fertilizer). NPK fertilizer (20-10-10) was applied at six weeks after planting (6WAP) at a rate of $120 \mathrm{~kg} / \mathrm{ha}$ in plots supplied with fertilizer only and $60 \mathrm{~kg} / \mathrm{ha}$ in plots supplied with prunings and fertilizer. The treatments were carried out in all the three production periods (May to July 2006, August to October 2006 and May to July 2007) and fertilizer application was by side placement.

The hedgerows were pruned at $50 \mathrm{~cm}$ from ground level and separated into wood and prunings. This was repeated during the cropping period at 6WAP. However the hedgerow of the species was cut once during the second planting period due to low biomass production. Wood was separated from the prunings and subsamlpes of these were oven dried at $60^{\circ} \mathrm{C}$ for 72 hours for prunings and $105^{\circ} \mathrm{C}$ for wood. The total dry weight of prunings and wood was then calculated. The prunings were spread uniformly on the alleys of the respective species.

Maize seeds var. CMS 8704 was planted at a distance of $0.5 \mathrm{~m}$ from the hedgerows and a spacing of $1 \times 0.5 \mathrm{~m}$. There were two plants per stand and the planting density was 40,000 plants/ha. The plots were managed with no tillage and weeds were controlled by spraying Roundup (glyphosate 21.12 $\mathrm{g} / \mathrm{L}$ ) before planting, followed by hand weeding at 4WAP or 6WAP. Weeds were assessed before hand-weeding was carried out.

Weed infestation was assessed by collecting weeds at 2 WAP and 4 WAP for the first planting and at 6WAP for the second and third planting. Three quadrats of $1 \times 1 \mathrm{~m}^{2}$ were chosen at random in each treatment to assess the weed diversity and density. Weed in the quadrats were manually uprooted and oven dried at $60^{\circ} \mathrm{C}$ for 72 hours and weighed in order to assess the weed biomass.

The height of the maize plants was measured at 6WAP and 8WAP with a graduated measuring rod. At 8WAP maize plants were sampled, oven dried at $60^{\circ} \mathrm{C}$ for a week in order to assess the nutrient uptake by nutrient difference method as described by Mulongoy and Van Der Meersch (1988). Maize was harvested at 14WAP and cobs were sub-sampled for 
each treatment, weighed and oven dried at constant weight at $35-40^{\circ} \mathrm{C}$. The cobs were shelled and the grain weights recorded.

The soil was randomly sampled at $0-5,5-15$, and 15 $-30 \mathrm{~cm}$ depths from the different plots. Soils at each soil depth for each treatment was bulked and mixed thoroughly to have a homogenous sample. The samples were labelled and air-dried in the laboratory. The air-dried samples were sieved with a $2 \mathrm{~mm}$ sieve. This was done before the first and after the three planting periods and the macronutrients, $\mathrm{pH}$, organic carbon and bulk density of the soils were analysed. Soil $\mathrm{pH}$ was determined in a 1/2.5 (w/v) soil/water suspension.

Organic $\mathrm{C}$ was determined by chromic acid digestion and spectrophotometric analysis (Heanes, 1984). Total $\mathrm{N}$ was determined from a wet acid digest (Buondonno et al., 1995) by colorimetric analysis (Anderson and Ingram, 1993). Exchangeable Ca, $\mathrm{Mg}$, and $\mathrm{K}$ were extracted using the Melhlich-3 method (Melhlich, 1984) and determined by atomic absorption spectrophotometry. Available $\mathrm{P}$ was extracted by Bray- 1 procedure and analysed using the molybdate blue method described by Murphy and Riley (1962). The data was analysed using Gentstat 8.0 software. ANOVA was used to assess the effects of the different treatments and for the cob and grain yield relationship, simple linear regression was carried out.

\section{RESULTS}

Biomass of prunings and wood output: There was significant differences in the biomass of prunings during the first planting with Callandria having the highest $(5314 \mathrm{~kg} / \mathrm{ha})$ and Gliricidia having the least (2112 kg/ha) at $P=0.05$ (Table 1). During the second and third planting, there was no significant difference in the pruning biomass between the different species. Senna had the highest pruning biomass $(149 \mathrm{~kg} / \mathrm{ha})$ and Callandria having the least $(53.0 \mathrm{~kg} / \mathrm{ha})$. Callandria pruning biomass during the third planting was highest $(1286 \mathrm{~kg} / \mathrm{ha})$ but it was not significantly different from that of Gliricidia which had the lowest biomass $(805.0 \mathrm{~kg} / \mathrm{ha})$ at $P<0.05$. Total nitrogen inputs from prunings in the first and third planting periods was significantly different $(P=0.05)$ and had ranges of $217.1-69.0 \mathrm{~kg} / \mathrm{ha}$ and $49.9-23.8 \mathrm{~kg} / \mathrm{ha}$ respectively. Callandria had the highest nitrogen inputs while Gliricidia had the least (Table 1). Nutrient concentrations in the prunings showed that Calliandria had the highest nitrogen $(4.09 \%)$ and magnesium $(0.40 \%)$ while Gliricidia had the highest potassium $(2.76 \%)$ and calcium concentrations $(1.08 \%)$ in the prunings (Table 2 )

Table 1. Biomass of prunings and wood and total Nitrogen input after successive prunings

\begin{tabular}{|c|c|c|c|c|}
\hline Planting Period & Species & $\begin{array}{l}\text { Wood biomass } \\
\text { (Mg/ha) }\end{array}$ & $\begin{array}{l}\text { Pruning biomass } \\
\text { (Kg/ha) }\end{array}$ & $\begin{array}{l}\text { N-input } \\
\text { From prunings } \\
\text { (Kg/ha) }\end{array}$ \\
\hline May & Callandria & 17.2 & 5314 & 217.1 \\
\hline \multirow[t]{4}{*}{$1^{\text {st }}$ planting } & Gliricidia & 25.7 & 2112 & 69.0 \\
\hline & Senna & 27.0 & 2909 & 115.9 \\
\hline & Mean & 23.3 & 3445 & 134 \\
\hline & L.S.D $(0.05)$ & 13.24 & 1293.3 & 51.45 \\
\hline August & Callandria & - & 53 & 2.2 \\
\hline \multirow[t]{4}{*}{$2^{\text {nd }}$ planting } & Gliricidia & - & 106 & 3.5 \\
\hline & Senna & - & 149 & 5.9 \\
\hline & Mean & - & 103 & 3.9 \\
\hline & L.S.D $(0.05)$ & & 226.7 & 8.83 \\
\hline \multicolumn{2}{|r|}{ Callandria } & 0.72 & 1286 & 49.9 \\
\hline \multirow[t]{4}{*}{$3^{\text {rd }}$ planting } & Gliricidia & 0.74 & 805 & 23.8 \\
\hline & Senna & 1.05 & 1184 & 42 \\
\hline & Mean & 0.84 & 1092 & 38.6 \\
\hline & L.S.D. $(0.05)$ & 0.682 & 787.1 & 28.91 \\
\hline
\end{tabular}


Table 2. Nutrient concentrations of Calliandra, Gliricidia, and Senna prunings.

\begin{tabular}{|l|l|l|l|l|l|}
\hline \multirow{2}{*}{ Species } & $\mathbf{N}$ & $\mathbf{P}$ & $\mathbf{K}$ & $\mathbf{C a}$ & $\mathbf{M g}$ \\
\cline { 2 - 7 } & 4 & & $\%$ & & \\
\hline Calliandra calothyrsus & 4.09 & 0.36 & 1.63 & 0.87 & 0.40 \\
\hline Gliricidia sepium & 3.26 & 0.41 & 2.76 & 1.08 & 0.36 \\
\hline Senna siamea & 3.98 & 0.40 & 2.36 & 1.03 & 0.25 \\
\hline
\end{tabular}

Crop growth and yield: During the first planting (Table 3) there was significant difference between treatments for plant height at 6WAP and plots supplied with Callandria prunings only had the highest height $(1.55 \mathrm{~m})$ while control had the least $(1.28 \mathrm{~m})$. Plant height was highly significant at 8WAP during the second planting (Table 3) with maximum in plots supplied with Senna prunings plus fertilizer $(3.34 \mathrm{~m})$ and minimum in control $(2.40 \mathrm{~m})$. Grain

yield was greater in plots supplied with Gliricidia prunings plus fertilizer (3963 $\mathrm{kg} / \mathrm{ha})$ and least in control (3039 kg/ha) respectively. In the second planting, cob yield was significantly different and plots supplied with Senna prunings plus fertilizer had the highest yield $(3368 \mathrm{~kg} / \mathrm{ha})$ and control the least (2779 $\mathrm{kg} / \mathrm{ha}$ ). Grain yield was not significantly different for the different treatments (Table 3).

Table 3. Effect of various treatments on maize growth and yield at first planting to third planting

\begin{tabular}{|c|c|c|c|c|c|c|c|c|c|c|c|}
\hline \multirow[b]{2}{*}{ Treatments } & \multicolumn{3}{|c|}{ FIRST PLANTING } & \multicolumn{4}{|c|}{ SECOND PLANTING } & \multicolumn{4}{|c|}{ THIRD PLANTING } \\
\hline & $\begin{array}{l}\text { Plant } \\
\text { height } \\
6 \text { WAP } \\
\text { (m) }\end{array}$ & $\begin{array}{l}\text { Cob yield } \\
(\mathrm{Kg} / \mathrm{ha})\end{array}$ & $\begin{array}{l}\text { Grain } \\
\text { yield } \\
\text { (kg/ha) }\end{array}$ & $\begin{array}{l}\text { Plant } \\
\text { height } \\
6 \text { WAP } \\
(\mathrm{m})\end{array}$ & $\begin{array}{l}\text { Plant } \\
\text { height } \\
\text { 8WAP } \\
(\mathrm{m})\end{array}$ & $\begin{array}{l}\text { Cob } \\
\text { yield } \\
\text { (kg/ha) }\end{array}$ & $\begin{array}{l}\text { Grain } \\
\text { yield } \\
\text { (kg/ha) }\end{array}$ & $\begin{array}{l}\text { Plant } \\
\text { Height } \\
\text { 6WAP } \\
(\mathrm{m})\end{array}$ & $\begin{array}{l}\text { Plant } \\
\text { Height } \\
\text { 8WAP } \\
(\mathrm{m})\end{array}$ & $\begin{array}{l}\text { Cob } \\
\text { Yield } \\
\text { (kg/ha) }\end{array}$ & $\begin{array}{l}\text { Grain } \\
\text { Yield } \\
\text { (kg/ha) }\end{array}$ \\
\hline Callandria & 1.55 & 3334 & 3210 & 1.63 & 3.25 & 2933 & 2264 & 2.02 & 2.95 & 5579 & 4248. \\
\hline Cal +fert & 1.50 & 4009 & 3559 & 1.66 & 3.23 & 3018 & 2531 & 2.11 & 2.92 & 5885 & 4696 \\
\hline Gliricidia & 1.43 & 4782 & 3860 & 1.58 & 3.11 & 2174 & 1708 & 1.92 & 2.70 & 5101 & 3964. \\
\hline $\begin{array}{l}\text { Senna }+ \\
\text { fert }\end{array}$ & 1.34 & 4740 & 3905 & 1.73 & 3.34 & 3368 & 2596 & 2.19 & 2.97 & 5687 & 4460. \\
\hline Fertilizer & 1.46 & 4297 & 3124 & 1.65 & 2.37 & 3063 & 2301 & 2.25 & 2.91 & 5640 & 4486 \\
\hline Control & 1.28 & 3877 & 3039 & 1.57 & 2.40 & 2047 & 1540 & 2.06 & 2.84 & 4339 & 3332 \\
\hline Mean & 1.44 & 4312 & 3555 & 1.62 & 2.97 & 2779 & 2210 & 2.06 & 2.85 & 5393 & 4182 \\
\hline $\begin{array}{l}\text { L.S.D } \\
(0.05)\end{array}$ & 0.13 & 1363.6 & 1042.5 & 0.20 & 0.25 & 714.60 & 566.10 & 0.16 & 0.21 & 358.20 & 391.30 \\
\hline
\end{tabular}

Table 4. The effect of planting position on maize growth and yield at second planting.

\begin{tabular}{|c|c|c|c|c|c|c|c|c|}
\hline \multirow{2}{*}{ Treatment } & \multicolumn{2}{|c|}{$\begin{array}{l}\text { Plant Height 6WAP } \\
(\mathrm{m})\end{array}$} & \multicolumn{2}{|c|}{ Plant Height 8WAP (m) } & \multicolumn{2}{|c|}{ Cob Yield (kg/ha) } & \multicolumn{2}{|c|}{ GrainYield (kg/ha) } \\
\hline & Edge & Middle & Edge & Middle & Edge & Middle & Edge & Middle \\
\hline Calliandra & 1.57 & 1.69 & 3.19 & 3.30 & 2475 & 3272 & 1840 & 2448 \\
\hline Gliricidia & 1.54 & 1.61 & 3.20 & 3.02 & 3122 & 2894 & 2391 & 2137 \\
\hline Gliricidia + Fert & 1.43 & 1.50 & 3.07 & 3.08 & 2006 & 2531 & 1500 & 1916 \\
\hline Fertilizer & 1.55 & 1.59 & 3.21 & 1.59 & 2855 & 3390 & 2153 & 2578 \\
\hline Control & 1.58 & 1.71 & 3.04 & 1.71 & 1881 & 2213 & 1425 & 1655 \\
\hline Mean & 1.60 & 1.64 & 3.13 & 2.81 & 2467 & 3091 & 2079 & 2342 \\
\hline L.S.D.(0.05) & \multicolumn{2}{|c|}{0.28} & \multicolumn{2}{|c|}{0.35} & \multicolumn{2}{|c|}{1010.70} & \multicolumn{2}{|c|}{800.60} \\
\hline
\end{tabular}

Each variable is compared along the rows for each treatment

WAP $=$ Weeks after planting 
Table 5. The effect of planting position on maize growth and yield at third planting.

\begin{tabular}{|c|c|c|c|c|c|c|c|c|}
\hline \multirow[t]{2}{*}{ Treatment } & \multicolumn{2}{|c|}{$\begin{array}{l}\text { Plant Height 6WAP } \\
(\mathrm{m})\end{array}$} & \multicolumn{2}{|c|}{$\begin{array}{l}\text { Plant Height 8WAP } \\
(\mathrm{m})\end{array}$} & \multicolumn{2}{|c|}{ Cob Yield (kg/ha) } & \multicolumn{2}{|c|}{ Grain Yield (kg/ha) } \\
\hline & Edge & Middle & Edge & Middle & Edge & Middle & Edge & Middle \\
\hline Calliandra & 2.00 & 2.04 & 2.88 & 3.01 & 5490 & 5668 & 4172 & 4323 \\
\hline Calliandra+ Fert & 2.08 & 2.14 & 2.80 & 3.04 & 5680 & 6089 & 4531 & 4861 \\
\hline Gliricidia & 2.03 & 1.82 & 2.60 & 2.80 & 5091 & 5111 & 3944 & 3984 \\
\hline Gliricidia + Fert & 1.92 & 1.95 & 2.51 & 2.80 & 5591 & 5532 & 4232 & 3967 \\
\hline Senna & 1.94 & 2.10 & 2.85 & 2.92 & 5119 & 5588 & 4022 & 4325 \\
\hline Senna + Fert & 2.17 & 2.21 & 2.99 & 2.94 & 5470 & 5904 & 4306 & 4615 \\
\hline Fertilizer & 2.25 & 2.25 & 2.90 & 2.91 & 5488 & 5792 & 4370 & 4603 \\
\hline Control & 2.10 & 2.03 & 2.79 & 2.90 & 4205 & 4474 & 3001 & 3662 \\
\hline Mean & 2.06 & 2.07 & 2.79 & 2.92 & 5267 & 5520 & 4072 & 4292 \\
\hline S.E.D. & \multicolumn{2}{|c|}{0.11} & \multicolumn{2}{|c|}{0.14} & \multicolumn{2}{|r|}{248} & \multicolumn{2}{|c|}{271} \\
\hline L.S.D. (0.05) & \multicolumn{2}{|c|}{0.23} & \multicolumn{2}{|c|}{0.30} & \multicolumn{2}{|r|}{506.50} & \multicolumn{2}{|c|}{553.40} \\
\hline
\end{tabular}

Each variable is compared along the row for each treatment WAP $=$ weeks after planting

In the third planting, (Table 3) plant height was significant at 8WAP with the maximum height in plots supplied with Senna prunings plus fertilizer $(2.97 \mathrm{~m})$ and least in plots supplied with Gliricidia prunings plus fertilizer $(2.66 \mathrm{~m})$. Grain yield was significantly different at $P=0.01$ and the highest was observed in plots supplied with Callandria prunings plus fertilizer $(4248 \mathrm{~kg} / \mathrm{ha})$ and least in control $(3332 \mathrm{~kg} / \mathrm{ha})$. The relationship between cob and grain yield showed a regression coefficient of about 0.79 (Figure 1 ).

Planting distance from the hedgerows had a negligible influence on the growth and yield of maize (Table 4 and 5) though maize plants in the middle (150 cm from border) showed an increase in yield than those at the edge (50 $\mathrm{cm}$ from hedgerows) and this, was not significantly different. This observation was also noted in control and plots supplied with fertilizer only.

Nutrient uptake of maize plants at tasselling: The nutrient concentration in maize plants at 8WAP in the third planting is shown in Table 6. Nitrogen concentration in maize plant ranged from 1.62-1.98 $\%$ with the highest in plots supplied with fertilizer only and least in control. The concentration of phosphorus ranged from $0.30-0.36 \%$ with a maximum in Senna plus fertilizer plots and the least in control plots.

Potassium concentration in maize plants ranged from $1.56-2.01 \%$ with a maximum in Senna plus fertilizer and minimum in control. The percentage of magnesium ranged from $0.21 \%$ in plots supplied with fertilizer only to $0.25 \%$ in Calliandra plots. Calcium concentration had a ranged of $0.24-0.26 \%$ with highest in plots supplied fertilizer only. The plots supplied with inorganic fertilizer only had the highest percentage of nitrogen uptake difference than plots supplied with prunings only (Table 6).

Weed biomass, density and diversity: Table 7 shows the weed biomass in the different plots. Weed biomass was reduced in plots supplied with pruning than in control plots. During the first and third planting, weed biomass was significantly different between the plots supplied with prunings and control. The least biomass was in plots supplied with Callandria $\left(80 \mathrm{~g} \mathrm{~m}^{-2}\right)$ and Gliricidia $\left(90 \mathrm{~g} \mathrm{~m}^{-2}\right)$ prunings for the respective planting periods. Weed biomass was highest in control plots in all the planting periods and it had a range of 167.50 to $307.30 \mathrm{~g}$ 
Table 6. Nutrient concentration of maize plant at tasseling at third planting.

\begin{tabular}{|l|l|l|l|l|l|l|l|}
\hline \multicolumn{3}{|c|}{ WEED BIOMASS $\left(\mathrm{g} / \mathrm{m}^{2}\right)$} & \multicolumn{3}{c|}{ WEED DENSITY Plants $/ \mathrm{m}^{2}$} \\
\hline Treatments & $\begin{array}{l}\text { First } \\
\text { planting }\end{array}$ & $\begin{array}{l}\text { Second } \\
\text { planting }\end{array}$ & $\begin{array}{l}\text { Third } \\
\text { planting }\end{array}$ & $\begin{array}{l}\text { First } \\
\text { planting } \\
\text { (2WAP) }\end{array}$ & $\begin{array}{l}\text { First } \\
\text { planting } \\
\text { (4 WAP) }\end{array}$ & $\begin{array}{l}\text { Second } \\
\text { planting } \\
\text { (6 WAP) }\end{array}$ & $\begin{array}{l}\text { Third } \\
\text { planting } \\
(6 \text { WAP) }\end{array}$ \\
\hline Callandria & 80.60 & 221.60 & 96.00 & 3 & 15 & 14 & 16 \\
\hline Gliricidia & 87.90 & 243.90 & 90.00 & 5 & 11 & 16 & 12 \\
\hline Senna & 139.30 & 245.60 & 122.80 & 13 & 27 & 25 & 18 \\
\hline Control & 248.30 & 307.30 & 167.50 & 40 & 56 & 32 & 20 \\
\hline Mean & 139.00 & 254.60 & 119.10 & 15.3 & 27.3 & 21.8 & 16.4 \\
\hline L.S.D (0.05) & 31.68 & 195.68 & 72.45 & 14.94 & 13.2 & 14.12 & 7.01 \\
\hline
\end{tabular}

Table7 : Weed biomass and Weed density in the different species and control

\begin{tabular}{|c|c|c|c|c|c|c|}
\hline Treatments & $\mathrm{N}$ & $P$ & $\mathrm{~K}$ & $\mathrm{Mg}$ & $\mathrm{Ca}$ & N uptake \\
\hline Calliandra & $1 \overleftarrow{82}$ & 033 & 173 & 025 & 02 & $\overrightarrow{12}$ \\
\hline Calliandra + fert & 1.97 & 0.32 & 1.79 & 0.24 & 0.26 & 21 \\
\hline Gliricidia & 1.78 & 0.31 & 1.94 & 0.24 & 0.24 & 9.0 \\
\hline Gliricidia + fert & 1.95 & 0.32 & 1.7 & 0.24 & 0.24 & 20 \\
\hline Senna & 1.80 & 0.33 & 1.82 & 0.24 & 0.26 & 11 \\
\hline Senna + fert & 1.97 & 0.36 & 2.01 & 0.22 & 0.24 & 21 \\
\hline Fertilizer & 1.98 & 0.32 & 1.9 & 0.21 & 0.26 & 22 \\
\hline Control & 1.62 & 0.30 & 1.56 & 0.24 & 0.24 & - \\
\hline
\end{tabular}

Weed density was significantly different $(P=0.05)$ in the alley plots and control for the three planting periods (Table 7). The weed diversity shifted from grasses to broad leaf species for plots supplied with fertilizer only and control. The initial weed species were Cyperus iria, Commelina benghalensis, Chromolaena odorata and Setaria megaphylla in almost all plots while Pennisetum purpureum was present in control and plots supplied with fertilizer only. The weed diversity increased with cropping period and the following species were observed; Ageratum conyzoides, Euphorbia hirta, Amaranthus caudatus, Cleome rutidosperma, Bidens pilosa, Curcubita mixta, Pureara phaseoloides, Chrankia leptocarpa, and Emilia coccinea.

Soil changes: Soil change is the difference between the soil properties before planting and after three cropping periods. Table 8 and 9 shows some soil properties before planting and after three planting periods respectively. There was a decrease in bulk density in most treatments after three planting periods except in plots supplied with Gliricidia and
Senna pruning. Soil bulk density had range from 0.74 $-0.96 \mathrm{~g} / \mathrm{cm}^{3}$ after planting.

There was a general increase in soil $\mathrm{pH}$ at soil depth $0-5 \mathrm{~cm}$ except plots supplied with fertilizer only which showed a decrease. The soil $\mathrm{pH}$ before planting had a range of $4.49-5.49$ while after planting the range was 4.37 - 5.04 ( Tables 8 and 9).

Soil organic carbon decreased in all the treatments at $0-15 \mathrm{~cm}$ soil depth. It had a range of $1.12-2.60 \%$ after planting with the highest in plots with Senna

prunings and the least in control at $15-30 \mathrm{~cm}$ soil depth (Table 9).

Soil total nitrogen $(\mathrm{N})$ generally decreased in all treatments and soil depths after planting. Total $\mathrm{N}$ had a range of $0.17-0.36 \%$ before planting (Table 8 ) after planting the range was $0.11-0.24 \%$ (Table 9). Total $\mathrm{N}$ after planting was highest was in plots supplied with Senna prunings only and Senna prunings plus fertilizer $(0-5 \mathrm{~cm})$ and least was in control at $15-30 \mathrm{~cm}$ soil depth (Table 9 ). 
Agric. Biol. J. N. Am., 2012, 3(3): 82-92

Table 8. Soil bulk density and chemical properties of soil before planting

\begin{tabular}{|c|c|c|c|c|c|c|c|c|c|c|}
\hline \multirow{2}{*}{ Treatments } & Soil Depth & Bulk Density & $\mathrm{pH}$ & Total N & $\mathrm{P}$ & $\mathrm{K}$ & $\mathrm{Ca}$ & $\mathrm{Mg}$ & \multirow{2}{*}{$\begin{array}{c}\text { Org C } \\
\%\end{array}$} & \multirow[t]{2}{*}{$\mathrm{C} / \mathrm{N}$} \\
\hline & $(\mathrm{cm})$ & $\mathrm{g} / \mathrm{cm}^{3}$ & Water & $\%$ & ppm & \multicolumn{3}{|c|}{\begin{tabular}{|c|c|}
------- \\
\end{tabular}} & & \\
\hline Callandria & $0-5$ & \multirow[t]{3}{*}{0.88} & 4.56 & 0.36 & 37.62 & 0.56 & 6.82 & 3.74 & 3.15 & 8.81 \\
\hline Callandria & $5-15$ & & 4.50 & 0.22 & 14.17 & 0.29 & 4.10 & 1.96 & 1.98 & 8.95 \\
\hline Callandria & $15-30$ & & 4.49 & 0.17 & 12.17 & 0.26 & 3.55 & 1.66 & 1.46 & 8.43 \\
\hline Gliricidia & $0-5$ & \multirow[t]{3}{*}{0.92} & 4.51 & 0.35 & 45.32 & 0.58 & 6.64 & 3.80 & 2.88 & 8.14 \\
\hline Gliricidia & $5-15$ & & 4.62 & 0.24 & 24.20 & 0.19 & 5.17 & 2.19 & 2.24 & 9.39 \\
\hline Gliricidia & $15-30$ & & 4.70 & 0.19 & 19.65 & 0.15 & 4.57 & 1.88 & 1.73 & 9.30 \\
\hline Senna & $0-5$ & \multirow[t]{3}{*}{0.92} & 4.96 & 0.27 & 36.71 & 1.01 & 7.88 & 2.58 & 2.97 & 11.00 \\
\hline Senna & $5-15$ & & 4.89 & 0.21 & 24.86 & 0.58 & 5.48 & 2.08 & 1.75 & 8.51 \\
\hline Senna & $15-30$ & & 4.83 & 0.17 & 23.39 & 0.57 & 4.60 & 1.90 & 1.41 & 8.30 \\
\hline Control & $0-5$ & \multirow[t]{3}{*}{0.92} & 5.49 & 0.30 & 52.74 & 2.30 & 10.89 & 4.36 & 2.99 & 9.93 \\
\hline Control & 5-15 & & 4.97 & 0.22 & 21.26 & 0.95 & 5.61 & 1.94 & 1.81 & 8.24 \\
\hline Control & $15-30$ & & 4.84 & 0.17 & 18.11 & 0.58 & 5.04 & 1.53 & 1.40 & 8.05 \\
\hline
\end{tabular}


Agric. Biol. J. N. Am., 2012, 3(3): 82-92

Table9. Soil bulk density and chemical properties of soil after three planting periods.

\begin{tabular}{|c|c|c|c|c|c|c|c|c|c|c|}
\hline Treatment & Soil Depth & Bulk Density & $\mathrm{pH}$ & Total N & Bray $\mathrm{P}$ & $\mathrm{K}$ & $\mathrm{Ca}$ & $\mathrm{Mg}$ & $\operatorname{Org} \mathrm{C}$ & $\mathrm{C} / \mathrm{N}$ \\
\hline & $(\mathrm{cm})$ & $\mathrm{g} / \mathrm{cm}^{3}$ & Water & $\%$ & $\mathrm{ppm}$ & \multicolumn{3}{|c|}{------cmol(+) kg-1----- } & $\%$ & \\
\hline Cal & $0-5$ & \multirow[t]{3}{*}{0.81} & 4.76 & 0.21 & 34.25 & 0.81 & 4.76 & 3.96 & 2.21 & 10.42 \\
\hline Cal & $5-15$ & & 4.73 & 0.19 & 27.34 & 0.57 & 4.34 & 3.31 & 1.91 & 10.21 \\
\hline Cal & $15-30$ & & 4.51 & 0.13 & 18.76 & 0.46 & 3.27 & 2.02 & 1.49 & 11.27 \\
\hline Cal + Fert & $0-5$ & \multirow[t]{3}{*}{0.74} & 4.91 & 0.24 & 33.07 & 0.91 & 4.68 & 2.91 & 2.49 & 10.40 \\
\hline Cal + Fert & $5-15$ & & 4.65 & 0.19 & 24.85 & 0.63 & 4.56 & 2.63 & 2.07 & 10.99 \\
\hline Cal + Fert & $15-30$ & & 4.46 & 0.12 & 18.69 & 0.30 & 3.32 & 1.90 & 1.25 & 10.30 \\
\hline Gli & $0-5$ & \multirow[t]{3}{*}{0.96} & 4.88 & 0.22 & 39.26 & 1.03 & 5.18 & 3.24 & 2.34 & 10.42 \\
\hline Gli & $5-15$ & & 4.53 & 0.17 & 24.39 & 0.43 & 3.75 & 2.22 & 1.79 & 10.68 \\
\hline Gli & $15-30$ & & 4.53 & 0.12 & 26.13 & 0.19 & 3.39 & 1.80 & 1.23 & 9.93 \\
\hline Gli + Fert & $0-5$ & \multirow[t]{3}{*}{0.90} & 4.81 & 0.23 & 42.53 & 0.95 & 4.35 & 2.59 & 2.36 & 10.38 \\
\hline Gli + Fert & $5-15$ & & 4.63 & 0.18 & 30.14 & 0.59 & 4.13 & 2.26 & 1.94 & 10.51 \\
\hline Gli + Fert & $15-30$ & & 4.49 & 0.13 & 29.45 & 0.27 & 3.55 & 1.83 & 1.36 & 10.18 \\
\hline Senna & $0-5$ & \multirow[t]{3}{*}{0.94} & 5.00 & 0.24 & 43.43 & 1.33 & 7.18 & 3.05 & 2.60 & 10.89 \\
\hline Senna & $5-15$ & & 4.85 & 0.19 & 35.71 & 0.92 & 5.85 & 2.55 & 1.98 & 10.52 \\
\hline Senna & $15-30$ & & 4.74 & 0.13 & 31.67 & 0.71 & 4.38 & 1.95 & 1.50 & 11.93 \\
\hline Senna + Fert & $0-5$ & \multirow[t]{3}{*}{0.91} & 4.95 & 0.24 & 44.41 & 1.29 & 6.31 & 3.17 & 2.50 & 10.34 \\
\hline Senna + Fert & $5-15$ & & 5.04 & 0.19 & 35.15 & 1.04 & 6.08 & 2.90 & 2.05 & 10.55 \\
\hline Senna + Fert & $15-30$ & & 4.40 & 0.13 & 28.42 & 0.76 & 3.41 & 1.88 & 1.38 & 10.60 \\
\hline Fertilizer & $0-5$ & \multirow[t]{3}{*}{0.86} & 4.83 & 0.22 & 33.83 & 0.73 & 5.03 & 2.57 & 2.22 & 10.18 \\
\hline Fertilizer & $5-15$ & & 4.47 & 0.17 & 26.38 & 0.43 & 4.08 & 1.91 & 1.90 & 10.98 \\
\hline Fertilizer & $15-30$ & & 4.39 & 0.11 & 22.41 & 0.29 & 2.76 & 1.33 & 1.23 & 11.15 \\
\hline Control & $0-5$ & \multirow[t]{3}{*}{0.95} & 4.92 & 0.22 & 27.55 & 0.79 & 3.99 & 2.41 & 2.19 & 9.96 \\
\hline Control & $5-15$ & & 4.75 & 0.17 & 22.90 & 0.47 & 3.24 & 1.80 & 1.67 & 9.77 \\
\hline Control & $15-30$ & & 4.37 & 0.11 & 15.63 & 0.24 & 2.62 & 1.26 & 1.12 & 9.92 \\
\hline
\end{tabular}




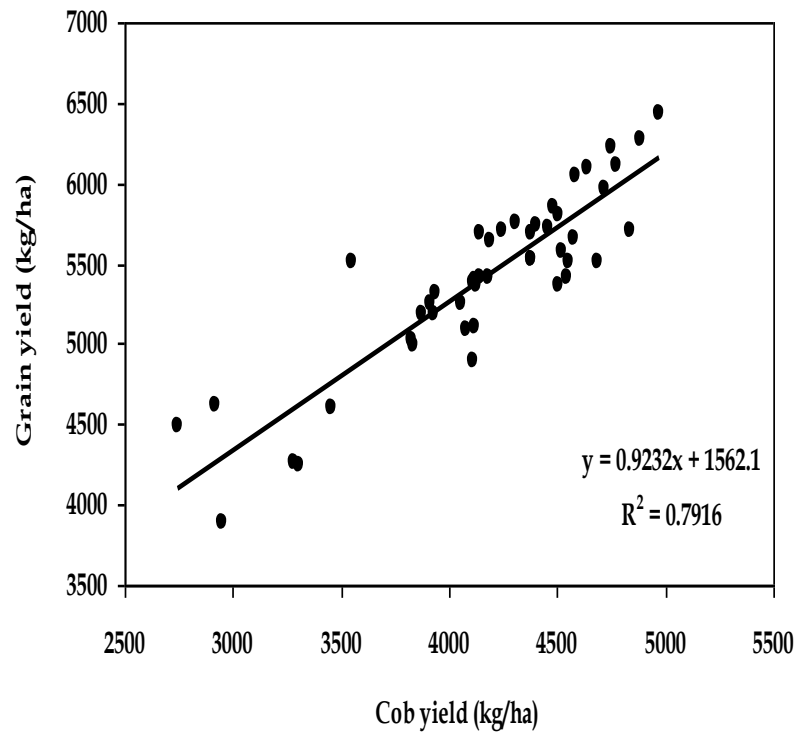

Fig 1. Simple linear regression between cob yields and grain yield

Soil phosphorus concentration decreases with soil depths and there was a general decrease in all the treatments except plots having Senna prunings or its prunings plus fertilizer. Phosphorus concentration before planting ranged from $12.17-52.74 \mathrm{ppm}$ and after plant it was $15.63-44.41 \mathrm{ppm}$ (Table 8 and 9).

Soil $\mathrm{K}$ changes after planting showed an increase in all treatments except in control and plots supplied with fertilizer only. After planting, soil $\mathrm{K}$ had a range of $0.24 \mathrm{Cmol} / \mathrm{kg}$ in control plots at the $15-30 \mathrm{~cm}$ soil depth, to $1.33 \mathrm{Cmol} / \mathrm{kg}$ in plots supplied with Senna prunings only (Table 9 ).

Soil magnesium generally decreased in plots supplied with fertilizer only and control. Magnesium had range of $1.53-4.36 \mathrm{Cmol} / \mathrm{kg}$ before planting and $1.53-4.36 \mathrm{Cmol} / \mathrm{kg}$ after planting (Tables 8 and 9).

The concentration of $\mathrm{Ca}$ in the soil before planting ranged from $3.55-10.89 \mathrm{Cmol} / \mathrm{kg}$ and after plant it was $2.62-7.18 \mathrm{Cmol} / \mathrm{kg}$. Calcium decreased in all the treatments after planting at the $0-15 \mathrm{~cm}$ soil depth (Tables 8 and 9).

There was a general increase in carbon to nitrogen ratio after planting when compared with the initial ratio before planting. After planting, the $\mathrm{C} / \mathrm{N}$ ratio ranged from 9.92 in control plots at soil depth $15-30$ $\mathrm{cm}$ to 11.93 in Senna plots at $15-30 \mathrm{~cm}$ soil depth (Table 9).

\section{DISCUSSION}

The results of this study show that the biomass of Callandria prunings was higher than that of Senna and Gliricidia. This may be due to the high branching habit of the species. (Ella et al.1989, Rosecrane et al.1992). However, during the second planting, it produced the lowest biomass because of its low initial coppicing ability but growth is rapid after about 2 or 3 months (Gutteridge 1990).

Wood biomass was not significantly different in the first and third planting period as these species had the potential to establish on acid soils. The wood biomass is similar to that obtained by Yamoah et al. (1986b) after three years of growth. The absence of wood biomass during the second planting was as a result of two successive pruning during the first planting period. Nitrogen input was highest in Callandria. This was a reflection of the $\mathrm{N}$ concentration in the prunings and the biomass of the prunings. Yamoah et al (1986b) and Lehman et al. (1998) observed that Callandria had a high nitrogen concentration in the leaves.

The cob and grain yields were least in control plots in all the three planting periods. This may be due no input from either green manure or inorganic fertilizer to improve on the yield

The high grain yield in plots supplied with prunings plus fertilizer and fertilizer only indicated that these supplied plant nutrients to the crops (Mandal et al 2003 and Yadav 2004). A higher cob and grain yield in the third planting than in the first planting might be as a result of green manure. Onim et al. (1990) reported similar results on the residual effects on green manure of Leucaena, Sesbania, and Cajanus species in cropping systems. Sharma and Acharya (2000) also indicated an increase in maize yield after three cropping seasons due to mulching with the cover crop Triticum aestivum.

A higher maize growth and yield in the middle row than in those at the edge might be due to interspecific competition between adjacent maize rows and the hedgerows species for plant resources. It may also be due to edge effects as those of the control showed the same pattern (Egbe et al 1998, Yamoah et al 1986b, and Kang et al 1981). Nutrient uptake was least in control due to the low availability of these nutrients in the soil while plots supplied with fertilizer only had the highest value due to the high 
and ready availability of these nutrients. Weed density and biomass was low in plots supplied with prunings when compared with the control plots. This was because these prunings acted as mulch which reduced germination and growth of weed seeds (Otu 1992). Weed diversity shifted over time from grasses to broad leaf species in control plot and this observation was also reported by Yamoah et al (1986a)

The decrease in soil bulk density at the $0-5 \mathrm{~cm}$ soil depth might be due to the slow decomposition rate of the prunings thus a decrease in the soil organic carbon content. This is because soil organic matter decomposes in mineral soils at rate of about $1-4 \%$ per year (Foth 1978). Similar results were recorded by Van Holm (1993) and Mandal (2003) who noted a decreased in bulk density at uppermost layer of the soil. The increase in soil $\mathrm{pH}$ might be due to the effect of the prunings which tend to improve on soil potassium and magnesium and therefore reducing the soil acidity.

A decrease in soil nitrogen, available phosphorus and calcium after three planting periods may due to uptake in grain filling and leaching especially nitrogen which is very mobile. Similar results were recorded by Mulongoy and Van Der Meersch (1988) who noted a decrease in soil phosphorus in alley cropping systems. There was an increase in potassium levels in all the treatments except in plots supplied with fertilizer only and control. This trend was similar for magnesium at $0-15 \mathrm{~cm}$ soil depth. This increase potassium may be due to the addition of the prunings which had high concentrations in the prunings of these tree legumes.

Soil organic carbon showed a decrease especially at the $0-15 \mathrm{~cm}$ soil depth. This may be as a result of the rate of decomposition of the plant material during planting periods. Varvel (2006) also stated a decrease in soil organic carbon after eight years of cropping while Sharma and Acharya (2000) indicated an increase in organic carbon after several cropping systems than in control at the $0-15 \mathrm{~cm}$ soil depth. The $\mathrm{C} / \mathrm{N}$ ratio showed an increase as a result of remarkable decrease in the nitrogen concentration of the soil after the three cropping periods. This is in corroboration with the findings of Odhiambo and Bomke (2007). In order to sustain crop production in the tropics the use of green/organic manure and the judicious use of inorganic fertilizers are very essential.
Acknowledgement: We wish to thank IRAD Ekona and staff for their material support during this study

\section{REFERENCES}

Abrams, M. M., Jarrell, W.M., Smith, H.A and Clark, P.R (1990). Nitrogen accretion in soil and biomass production by three Prosopis species. Agroforest Syst 10:93-97.

Anderson, J.M and Ingram, J.S.I (1993). Tropical Soil Biology and Fertility: A handbook of methods. Second edition. CAB International. The Cambrian News, Aberstwyth, United Kingdom. 221 p.

Barrio, E and Cobo, J.G (2004). Plant growth, biomass production and nutrient accumulation by slash/mulch agroforestry systems in tropical hillsides of Colombia. Agroforestry Systems 60 :255-265.

Belsky, A.J., Mwonga, S.M and Duxbury, J.M (1993). Effects of widely spaced trees and livestock grazing on understory environments in tropical savannas. Agroforest Syst 24:1-20.

Buondonno, A., Rashad, A. A and Coppola, E. (1995). Comparing tests for soil fertility. 11. The hydrogen peroxide/sulfuric acid treatment as an alternative to the copper/selenium catalyzed digestion process for routine determination of soil nitrogen-Kjeldahl. Comm in Soil Sci and Plant Analy 26:1607-1619.

Egbe, E.A., Ladipo, D.O., Nwoboshi, L.C and Swift, M.J (1998). Potentials of Millettia thonningii and Pterocarpus santalinoides for alley cropping in humid lowlands of West Africa. Agroforest Syst 40: 309-321.

Ella, A., Jacobsen, C., Stier, W.W and Blair G.J (1989). Effect of plant density and cutting frequency on the productivity of four tree legumes. Trop Grasslands 23: 28-34.

FAO-UNDP/IRA-EKONA (1977). Soil surveys and land evaluation of Ekona banana estate. Cameroon Development Corporation (CDC) Technical Report. Ekona Cameroon. 170p

Foth, H.D (1978). Fundamentals of soil Science. John Wiley and Son, Inc New York

Fu, M.H., Yu, X.C and Tabatabai, M.A (1987). Effects of pH on nitrogen mineralization in crop-residue-treated soils. Biol Fert Soils 5: 115-119.

Gutteridge, R.C (1990). Agronomic evaluation of tree and shrub species in Southeast Queensland. Trop Grasslands 24 (1): 29-36.

Heanes, D.L (1984). Determination of organic carbon in soils by an improved chromic acid digestion and spectro-photometric procedure. Comm. Soil Sci. And Plant Analy 15:1191-1213.

Hobbie, S.E (1992). Effects of plant species on nutrient cycling. Trends in Ecol and Evol 7:336-339. 
Hseih, S.C and Hseih, C.F (1990). The use of organic matter in crop production. Extension Bulletin 315, Food and Fertilizer Technology Centre, Tapei, Taiwan, Republic of china. 19p

Jaiyebo, E.O, and Moore, A.W (1964). Soil fertility and nutrient storage in different soil vegetation systems in tropical rain forest environment. Trop Agric 41:129136.

Jama, B., Palm, C.A., Buresh, R.J., Niang, A., Gachengo, C., Nziguheba, A.B. (2000). Tithonia diversifolia as a green manure for soil fertility improvement in western Kenya: a review. Agroforest Syst 49: 201- 221.

Kang, B.T., Wilson, G.I and Lawson, T.L (1981). Alley cropping maize(Zea mays $\mathrm{L})$ and Leucaena leucocephala (Lam) in southern Nigeria. Plant and Soil 63: 165-178

Lehmann, J., Schroth, G and Zech, W (1998). The influence of agroforestry systems on soil organic matter properties and nitrogen content of a plinthic acrisol in central Togo. In Duguna B, Mallet B. (1998). Regional symposium on agroforestry research and development in the lumid lowlands of west and central Africa. Pp 255-262. .

Mandal, K., Singh, G., Victor, U.S and Sharma. K.L (2003). Green manure: it's effects on soil properties and crop growth under rice-wheat cropping system. European Jr of Agron. 192: 225-237

Mazzarino, M.J., Oliva, L., Nunez, A and Nunez, G.B (1991). Nitrogen mineralization and soil fertility in the dry chaco ecosystem (Argentina). Soil Sci Soc of Amer Jr 55:515-522.

McDonald, M.A., Stevens, P.A and Headley, J.A (2004). Soil fertility under Calliandria calothyrsus hedgerows and other land-use treatments following forest clearance in Jamaica. Agroforest Syst 57 127-135.

Mehlich, M (1984). Mehlich 3 soil test extractant: Modification of the détermination of the Mehlich 2 extractant. Comm in Soil Sci \& Plant Analy 15: 14091416.
Mulongoy, K and Van Der Meersch M.K (1988). Nitrogen contribution by Leucaena (Leucaena Leucocephala) prunnings to maize in an alley cropping system. Biolog Fert Soil 6: $282-285$.

Murphy, J and Riley, J.P (1962). A modified single solution method for determination of phosphate in natural waters. Analy Chimica Acta 27:31-36.

National Cereals Research and Extension project (NCRE) (1991). Helping to guarantee a nutritious and sustainable food supply for Cameroon. 40 p.

Ndam, N (1998). Tree regeneration, Vegetation dynamics and maintenance of biodiversity on Mount Cameroon: Relative impact of natural and human disturbance. PhD thesis, University of Wales, Bangor UK

Onim, J.F.M., Mathuva, M., Otieno, K. and Fitzhugh, H.A (1990). Soil fertility changes and response of maize and beans to green manures of Leucaena, Sesbania and pigeonpea. Agroforest Syst 12: 197-215.

Otu, O.I. (1992). Effects of Gliricidia Sepium (Jacq. Steud) on yam yield in Southwestern Nigeria. PhD. Thesis in the department of Agronomy. University of Ibadan Nigeria.

Odhiambo, J.O and Bomke A.A (2007). Cover crop effects on spring soil water content and the implications for cover crop management in South Coastal British Columbia. Agric. Water Manage. 88. 1-3. 92- 98.

Rosecrane, R.C., Rogers, S and Tofinga, M (1992). Effects of alley cropped Calliandra calothyrsus and Gliricidia sepium hedges on weed growth, soil properties and taro yields in Western Samoa. Agroforest Syst 19: 5766.

Sharma, P.K, and Acharya, L (2000). Carry-over of residual soil moisture with mulching and conservation tillage practices for sowing of rainfed wheat (Triticum aestivum L.) in north-west India. Soil and Till Res 57. 1-2: 43-53. 